\title{
Speech Functions of Male and Female Lecturers in the Classroom Interaction
}

\author{
Ummul Mawaddah Rangkuti \\ English Applied Linguistics Study Program \\ State University of Medan \\ Medan, Indonesia \\ mawaddah_ummul@yahoo.com \\ Amrin Saragih \\ English Applied Linguistics Study Program \\ State University of Medan \\ Medan, Indonesia \\ Rahmad Husein \\ English Applied Linguistics Study Program \\ State University of Medan \\ Medan, Indonesia
}

\begin{abstract}
This research deals with speech functions of male and female lecturers in the classroom interactions at Universitas Muslim Nusantara (UMN) Al-Washliyah Medan. The objective of this study was to investigate the types of speech function made by male and female lecturers in the classroom interactions at Universitas Muslim Nusantara (UMN) Al-Washliyah Medan. Case study was conducted for this research. The data of this research were utterances of male and female lecturers in the classroom interactions. The data were collected by audio recording by following some steps identifying and classifying. The results of this research showed that the types of speech functions that have been found in male and female lecturers in the classroom were statement, question, command, offer, and minor. Which is the statement is more often used by male lecturer in the classroom interactions, then it is followed by question, command, offer and minor. While, the question is more often used by female lecturer in the classroom interactions, then it is followed by statement, command, offer and minor. In addition, based on speech functions of male and female lecturers in the classroom interactions, it was found that the way of male and female lecturers at Universitas Muslim Nusantara (UMN) Al-Washliyah Medan still dominated lecturer centre in doing teaching.
\end{abstract}

Keywords-speech functions; male and female lecturers; classroom interactions

\section{INTRODUCTION}

Language has function to fulfill human needs in the exchange of experience, such as teaching learning process. Teaching learning process takes place mostly in classrooms and it is frequently carried out under the guidance and supervision of teachers or lecturers. The interaction between teachers or lecturers and students constitutes the most important part in all classroom activities. In addition, the appropriate speech functions of lecturers can create harmonious atmosphere and at the same time promotes a more friendly relationship between lecturers and students.

Speech functions is an action or performance done by language users such as asking, commanding and answering in order to fulfill the intention of the speakers and listeners [1] states that. It is used as the medium exchange of their experiences. Speech function is more oriented to functional interpretation, especially systemic functional linguistics (SFL). It means that all the utterances involved the four types in speech functions (statement, question, offer, and command).

Speech functions are a semantic aspect of meaning which is realized by mood at the level of lexicogrammar [2]. In this study, all the speech functions should be coded by three moods, namely declarative, interrogative, and imperative. All of these are the representations of human beings utterances in their communication. Therefore, speech function is used to exchange human's experiences through language function by using interpersonal function and coded by mood.

When human being interacts in community, they perform interpersonal function of language. Interpersonal function is realized by mood and modality. Mood shows what role the speaker selects in the speech situation and what role he assigns to the addressee. If the speaker selects the imperative mood, he assumes the role of one giving commands and puts the addressee in the role of one expected to obey orders. Modality specifies if the speaker is expressing his judgment or making a prediction [3].

The interpersonal function is realized at two levels namely at the level of (discourse) semantics and lexicogrammar. At the level of semantics, human being performs two roles namely Giving and Demanding. The commodity exchange 
may be either information or Goods \& Services. When the roles and commodities are cross classified, four specific activities or speech functions are derived. Based on Halliday [3] states that speech functions are realized in four types, namely: statement, question, offer and command. Thompson [4] emphasizes the important point that use of language lies at the very heart of social life. In general, it is noted that communication and language are important components of social life. Expressing thought and felling, conveying ideas, making request giving command, and so on.

Some studies on this field have been done, for examples Yuliati [5] who examined interpersonal meaning negotiation in the teacher-student verbal interaction. She found that most of the utterances produced by the teacher were in the form of command which means that the authority of the teacher was dominant. However, the teacher also tried to be equal with the students by using some declarative and interrogative types of mood. These made the students respond well but not really elaborated her/his responses. Ayoola [6] also examined that an interpersonal metafunction analysis of some selected political advertisements in some nigerian newspapers had the differences in the distribution of mood types in the adverts of the two political parties as well as their interpersonal meanings are determined by contextual factors such as the need to reflect the economic and socio-political context/situation of the country. In addition, Fikri [7] found that there are some differences of male and female teacher talk in selecting Mood system in expressing interpersonal meaning to the students i.e. in giving information, in asking a question, in demanding the students to do something, and in offering something to the students. Cultural and social factor of the teachers are believed as the contributions to the differences.

In order to undergo this research, the data were taken from male and female lecturers of Universitas Muslim Nusantara Al-Washliyah, Medan. By adapting this theory the researcher took several utterances from one male lecturer and one female at English Department. This study focused on their utterances produced by male and female lecturer at Universitas Muslim Nusantara Al-Washliyah, Medan while teaching in the classroom.

Therefore, this study was aimed to find out the types of speech functions are made by male and female lecturers in the classroom interactions at Universitas Muslim Nusantara AlWashliyah, Medan.

\section{REVIEW OF LITERATURE}

\section{A. Theory of Speech Function}

Speech function is an action or performance one by language user such as: asking, commanding and answering in order to fulfill the intention of the speakers and listeners [3]. Speech function is used as the medium to exchange their experiences. Speech function is more oriented to functional interpretation, specifically systemic functional, which means that all the utterances uttered the four types of speech functions. The four primary speech functions, see in the Table 1.
TABLE 1. Speech Functions by Halliday \& Matthiessen (2014)

\begin{tabular}{llll}
\hline & Commodity & \\
\hline Role & Information & $\begin{array}{l}\text { Good } \\
\text { Services }\end{array}$ & \& \\
\hline Giving & Statement & Offer & \\
\hline Demanding & Question & Command & \\
\hline
\end{tabular}

1. Command: linguistic expression for demand something to other.

Example: Borrow me your pen!

2. Offer: linguistic expression to give something to other. Example: Can I help you!

3. Statement: Linguistic expression to inform the hearer Example: I am a lecture

4. Question: Linguistic expression to asking the hearer Example: How old are you?

\section{B. Gender in Language}

Gender is different from other forms of social inequality in that men and women interact extensively within families and households and in other role relations [8]. Gender refers to values, rights and responsibility socially and culturally given to someone due to or as the consequences of the fact that $\mathrm{s} / \mathrm{he}$ is male or female. This is to say that it is the society that makes someone masculine or feminine with rights and responsibillity attached to each status. In other words, whenever we meet a person, the first thing that comes to one's mind is whether the person is male or female, and accordingly, the person interprets in terms of gender. For instance, one may prefer men to occupy high and authoritative positions, and relate women to lower and subordinate roles or activities. Consequently, people are socialized according to the gender knowledge which influences our thinking and perception about the other, thinking of others in terms of gender is almost inescapable [9].

As stated above, the differences between the sexes can be noticed at the level of social, cultural, religious, economic, and political spheres, and also at the level of language. Concerning language, males and females may adopt different characteristic when speaking to each other.

\section{Male and Female Teacher in the Classroom Interactions}

Many definitions of teacher language have been given from different perspectives. One definition goes that teacher language is the language in the classroom that takes up a major portion of class time employed to give directions, explain activities and check students' understanding [10]. As an indispensable part of foreign language teaching, teacher language has its own features in that both the content and the medium are the target language. The language employed by teachers in language classes is served as the source of input of language knowledge, and also used to instruct language communication and organize classroom activities. Moreover, teacher language plays a very important role in the teaching process as an interactive device. For teachers would employ a lot of interactive devices such as repetition, prompting, 
prodding, and expansions, which would be evoking more interactions between teachers and students.

\section{METHODOLOGY}

This study was conducted by using a single case study research design. Case study research is a qualitative approach in which the investigator explores a bounded system (a case) or multiple bounded systems (cases) over time, through detailed, in-depth data collection involving multiple sources of information (observations, interviews, audiovisual material and documents and reports) and report a case of description and case-based theme [11]. Thus, a case study research involves the study of an issue explored through one or more cases within a bounded system (setting and context).

The data of this study were particularly the clauses of male lecturer and female lecturers in the classroom interactions which speech function realized in mood. In which their utterances are uttered in English language use among them and concerned on their gender as well. Furthermore, data sources of this study were one male lecturer and one female lecturer who teach in the English Department at the University of Muslim Nusantara Al-Washliyah (UMN-AW) Medan.

The data were collected through audio recorder when male or female lecturers were taking place in the classroom interactions. The instrument of collecting the data were audio recorder, observation sheet, and taking note. This research was taken from the audio recorder in the classroom of male and female lecturers. Before analyzing the data, the research was identified and classified whether the data that belonging to speech functions of male and female lecturers were taking place in the classroom interactions.

The data will be analyzed by interactive model classified officially Miles, Huberman \& Saldana[12] In this analysis, it is by ongoing analysis and after collecting the entire the data (Miles, Huberman \& Saldana, 2014). Purpose an analysis as three concurrent flowed of activity: (1) data condensation, (2) data display, and (3) conclusion drawing / verification.

\section{FINDINGS AND DISCUSSION}

After analyzing the data, the data are classified based on the types of speech functions. There are four types of speech functions of male and female lecturers and one new type that have been found in the classroom interactions. They are statement, question, command, offer and minor, see in Table 2.

TABLE 2. Types of Speech Functions of Male and Female Lecturers in the Classroom Interactions

\begin{tabular}{lllll}
\hline $\begin{array}{l}\text { Speech } \\
\text { Functions }\end{array}$ & $\begin{array}{l}\text { Clauses of } \\
\text { ML's } \\
\text { Utterances }\end{array}$ & Percentage & $\begin{array}{l}\text { Clauses of } \\
\text { FL's } \\
\text { Utterances }\end{array}$ & Percentage \\
\hline Statement & 97 & 77.60 & 78 & 38.80 \\
\hline Question & 19 & 15.20 & 90 & 44.77 \\
\hline Command & 7 & 5.60 & 25 & 12.43 \\
\hline Offer & 2 & 1.60 & 4 & 2.00 \\
\hline Minor & - & - & 4 & 2.00 \\
\hline Total & $\mathbf{1 2 5}$ & $\mathbf{1 0 0}$ & $\mathbf{2 0 1}$ & $\mathbf{1 0 0}$ \\
\hline
\end{tabular}

Based on Table 2 above it can be seen that, the types of speech functions that have been found from male lecturer in the classroom were statement, question, command, offer, and minor of response (acceptance). The male lecturer have produced the statement were $97(77.60 \%)$ so that it can be categorized as usually, while question were $19(15.20 \%)$ that can be categorized as often, command were $7(5.60 \%)$ that can be categorized as sometimes, offer were $2(1.60 \%)$ that can be categorized as rarely.

Furthermore speech functions of female lecturer found in the classroom were statement, question, command, offer, and minor of response. The female lecturer have produced the statement were $78(38.80 \%)$ so that it can be categorized as often, while question were $90(44.77 \%)$ that can be categorized as usually, command were $25(12.43 \%)$ that can be categorized as sometimes, offer were $4(2.00 \%)$ that can be categorized as rarely then minor were $4(2.00 \%)$ that can be categorized as rarely.

Based on the table, all types of speech functions occurred in the classroom interactions. It was also found a new type of speech function that is minor of response (acceptance). Minor of response (acceptance) was used only by female lecturers. Meanwhile, the dominant type of speech function which was used by male lecturer is statement. It was different from other research who did not find minor of response (type of acceptance) used by female educators. It happened because Indonesian female prefer doing small talk before teaching learning process. It indicates that culture and gender contributes to speech function influence.

\section{ACKNOWLEDGMENT}

The writer would like to express respectfulness to Prof. Amrin Saragih, M.A., Ph.D and Dr. Rahmad Husein, M.Ed as her thesis advisor for guiding her to accomplish her thesis and for giving useful knowledge and suggestions.

\section{REFERENCES}

[1] Ye, J. 2006. Traditional and online support networks in the crosscultural adaptation of Chinese international students in the United States. Journal of Computer-Mediated Communication, 11(3), 863-876.

[2] Martin, J. R. 1992. English text: System and structure. John Benjamins Publishing.

[3] Halliday, M A K \& Matthiessen Christian M.I.M, 2014. Hallidays'Introduction to functional Grammar. $4^{\text {th }}$ Edition. London: Routledge.

[4] Thompson, N. 2010. Theorizing social work practice. Palgrave Macmillan.

[5] Yuliati. 2015. Interpersonal Meaning Negotiation in the Teacher-Student Verbal Interaction. Indonesia : Semarang State University.

[6] Ayoola, \& Olusanya, M. 2013. An Interpersonal Metafunction Analysis of Some Selected Political Advertisements in Some Nigerian Newspapers. International Journal of Humanities and Social Science. Vol. 3 No. 8.

[7] Fikri, Z. 2015. Mood Structure analysis of teacher Talk in EFL Classroom: A Discourse Study Based on Systemic Functional Linguistic Theory. GaneC Swara. 9(1), 86-95.

[8] Ridgeway, C. L., \& Smith-Lovin, L. 1999. The gender system and interaction. Annual review of sociology, 25(1), 191-216.

[9] Wareing, S. 2004. Language and gender. Cambirgde University Press. 
[10] Sinclair, J. M., \& Brazil, D. 1982. Teacher Talk. Oxford University Press.

[11] Creswell, J. W. 2007. Five qualitative approaches to inquiry. Qualitative inquiry and research design: Choosing among five approaches, 2, 5380.
[12] Miles, M. B., Huberman, A. M., \& Saldana, J. 2014. Qualitative data analysis 3rd Edition: Source book of Bew Methods. Baverly Hills: SAGE Publications Inc. 